\title{
The Dimension of the Body in Higher Education: Matrix of Meanings in Students' Diaries
}

\author{
Ramiro Tau $^{1}$ (D) . Laure Kloetzer ${ }^{1}$ (D) . Simon Henein ${ }^{2}$ (D) \\ Received: 23 August 2020 / Revised: 30 January 2021 / Accepted: 15 March 2021 / \\ Published online: 26 March 2021 \\ (c) The Author(s) 2021
}

\begin{abstract}
In this paper, we attempt to show some consequences of bringing the body back into higher education, through the use of performing arts in the curricular context of scientific programs. We start by arguing that dominant traditions in higher education reproduced the mind-body dualism that shaped the social matrix of meanings on knowledge transmission. We highlight the limits of the modern disembodied and decontextualized reason and suggest that, considering the students' and teachers' bodies as non-relevant aspects, or even obstacles, leads to the invisibilization of fundamental aspects involved in teaching and learning processes. We thus conducted a study, from a socio-cultural perspective, in which we analyse the emerging matrix of meanings given to the body and bodily engagement by students, through a systematic qualitative analysis of 47 personal diaries. We structured the results and the discussion around five interpretative axes: (1) the production of diaries enables historicization, while the richness of bodily experience expands the boundaries of diaries into non-textual modalities; (2) curricular context modulates the emergent meanings of the body; (3) physical and symbolic spaces guide the matrix of bodily meanings; (4) the bodily dimension of the courses facilitates the emergence of an emotional dimension to get in touch with others and to register one's own emotional experiences; and (5) the body functions as a condition for biographical continuity. These axes are discussed under the light of the general process of consciousness-raising and resignification of the situated body in the educational practice.
\end{abstract}

Keywords Higher education $\cdot$ Body $\cdot$ Diaries $\cdot$ Embodied learning $\cdot$ Performing arts

Ramiro Tau

ramiro.tau@unine.ch

Laure Kloetzer

laure.kloetzer@unine.ch

Simon Henein

simon.henein@epfl.ch

1 Institut de psychologie et éducation, Université de Neuchâtel (UNINE), Esp. Tilo-Frey 1, 2000 Neuchâtel, Switzerland

2 Instant-Lab, École Polytechnique Fédérale de Lausanne (EPFL), Rue de la Maladière 71b, 2002 Neuchâtel, Switzerland 
The place of the body in formal educational contexts has been a topic of growing interest in the last three decades (Barnacle, 2009; Craig et al., 2018; Evans et al., 2009; Gallo, 2017; Matthews, 1994; McNeill, 1992; Núñez et al., 1999; Planella, 2006; Varela et al., 1991; Seitz, 2000; Streeck et al., 2011; Welton, 1999). However, most scientific publications on this subject dealt with primary or secondary schooling, referring to it, polysemically, as somatic, bodily, spatial, or integrative learning (Barnacle, 2009; Bresler, 2013; Dixon \& Senior, 2011; Druyan, 1997; Glenberg, 2010, 2017; Nguyen \& Larson, 2015; Scharagrodsky, 2007; Stolz, 2015). More recently, different studies focused on the functions of the body in university teaching and research settings (among many others: Bunglowala \& Bunglowala, 2015; Dall'Alba \& Barnacle, 2005; Gallagher \& Lindgren, 2015; Hodkinson Biesta \& James, 2008; Kazan, 2005; Probyn, 2004; Shoval, 2011). In general terms, these works highlighted, from different theoretical frameworks, that the production of knowledge-the main declared goal in university statutes (Perkin, 2007)-cannot be conceived as a disembodied (Bresler, 2013) and decontextualized activity (Freire, 1996; Sidhu \& Dall'Alba, 2012). In other words, they discussed the inherited conception of an ahistorical subject of education, universal and, fundamentally, conceived from a rationality purified of all somatism (Abbagnano \& Visalberghi, 2015; Giroux, 1992).

In this direction, the emphasis acquired by the abstract reason as a separable and exclusive substance of teaching and learning processes (Nguyen \& Larson, 2015) is often criticized (Damasio, 1994). Although Western education systems have dealt with the body and its education, they have done so by re-editing a relationship that recalls that of the contained continent, a meaning that perfectly captures the old dictum "mens sana in corpore sano", often repeated in the world of education (Paechter, 2004). Additionally, education as a social praxis is part of a complex system of institutions, notions, beliefs and values legitimized and shared by a group. In a very broad way, we can say that the orientation of educational actions is inscribed in a matrix of meanings ${ }^{1}$ that transcends the borders of the educational organization and crosses culture in all its dimensions (Tau \& Parrat-Dayan, 2018). It is, therefore, necessary to identify this matrix of naturalized meanings and practices implied in the acquisition and development of knowledge, with the objective of being able to pose some problems related to the role of the body in formal learning processes.

In this article, we first try to highlight, as several researchers have noted, that the extended conception of a "disembodied" knowledge is the result of a series of meanings belonging to common sense but also to politics, as well as to post-enlightenment philosophical and scientific traditions, that today are reproduced and amplified in contemporary discourses (Damasio, 1994; Davis, 1996; Luzuriaga, 1997; Paechter, 2004), also in some new versions of neuroscience-based education (Castorina, 2016). With the aim of contributing to the discussion on the effects of these dichotomic conceptions, in this paper, we focus on what happens when the body and bodily engagement are put back at the core of the pedagogical experience. To do so, we present some findings from our ASCOPET research project (Les Arts de la Scène comme Outil Pédagogique dans l'Education Tertiaire, or in English Performing Arts as Pedagogical Tools in Higher Education), which

\footnotetext{
1 The notion "matrix of meanings" that we are using here is deliberately vague. On the one hand, it is evocative of the notion of social institutions, from the major currents of classical sociology, from Durkheim to Castoriadis, that is, a form of regulation of interactions that is reproduced in their very existence. In our case, the matrices are much more unstable and less structured. The meanings, values and norms that compose these matrices can, but do not necessarily, coincide with some instituted practices. However, our study does not focus on these institutions, but rather on the particular meanings that emerge from a personal experience to which we cannot attribute a structure or a reproductive function.
} 
seeks to analyse and understand the specific teaching and learning processes that take place in courses that make use of performing arts-improvisation and theatre-in higher education, with students from engineering and psychology programs. In particular, we will show how an innovative pedagogical approach that proposes a transformation of the traditional statute of the body can have radical consequences in the way students relate to the content to be taught, to their peers, to the institution and to teachers. Finally, we will discuss the possible generalization of the results achieved and we will mention some of their potential political consequences.

\section{The Splitting Inheritance}

\section{Inheriting Dualism From Philosophy}

Undoubtedly, one of the turning points in the configuration of modern thought was the work of René Descartes and the so-called "subjectivist turn" (Assalone \& Misseri, 2010; Gaukroger, 1995; Gillespie, 2008). As a direct reaction to medieval dogmas, Cartesian rationalism opened an epistemic trust in a reason that lies beyond revelations or any sensitive experience of the internal or external world. With this transformation of classical understandings on the psyche-soma relation (Wright \& Potter, 2000), the guarantee for valid knowledge rested exclusively on the activity of thought and detached itself from other experiences. Indeed, a posteriori knowledge of perceptions and intuitions, far from allowing access to an indubitable truth, was conceived as one of the inevitable sources of confusion and error (Maresca, 2010).

In this way, Descartes' rationalism-and also that of Leibniz or Spinoza, in a different way-established the bases of the fundamental cleavage that allowed to dissect, in a surgical way, the mind from the body. From this perspective, body and mind are two different substances that, in humans, are reunited, although in an uncertain way (Castorina, 2002; Gobert, 2013). Anyway, both substances suppose a capital asymmetry since the epistemic value of each one is significantly different. In fact, here, the body cannot be the support of any knowledge; only the disembodied reason, the res cogitans, is a guarantee for the access to clear, simple and indubitable truth. This dualistic thesis transcended the frontiers of philosophy and oriented idealistic theories and metatheories, as well as scientific research methodologies (Villoro, 2013). A remarkable case of this ontological heuristic guide was the anatomical-physiological search for the connection between both substances, an attempt to find the seat of the mind-the soul-in the domain of the res extensa (Alanen, 2009; LópezMuñoz et al., 2010; Lokhorst \& Kaitaro, 2001), or, as ironically stated by Gilbert (1949) when referring to this categorical error, the search for the "ghost in the machine".

In its different versions, the reaction of empiricism against rationalism also rested, in its own way, on some form of fundamental dualism. The thesis that states that all knowledge has an anchorage in some observational source implied the distinction of different sensitive appearances. It also implied the reduction of complex forms to their most fundamental components (Feigel, 1950; Hill, 2018), an idea that is finally sophisticated with the distinction between analytical truths and synthetic truths (Quine, 1976). In the same way, the modern empiricist tradition re-edited the radical dissociation between the subject of knowledge and the object to be known, placing the accent on the other extreme of this duality. But much more fundamentally, it configured, by another argumentative path, an exacerbation of the mental and, in this way, another of the foundations of the modern 
representational subjectivity, irreversibly split from the body. Although paradoxical, in this empirical tradition, "experience" must always be understood as some kind of mental phenomenon and not as a relation with a previous and independent reality, existing before any encounter with the knowing subject. This is clear, for example, in Hume's work-and in particular in his conception of impressions and experience-where the "objective world" is nothing more than the result of an imagination regulated by the principles of association. Even the two types of relations that reason can establish-relations between facts and relations between ideas-are essentially different. While relations between facts are contingent, and from there, the conception of the causal connection as a mere inference based on repetition, only relations between ideas are necessary. At the same time, it is the "reflexive" processes that allow the access to some kind of knowledge, beyond the "ideas"-in the sense of Locke or Berkeley-or the "sensations"-Hume-that get into the subject. In short, ontological dualism and the epistemological approaches of rationalism and empiricism "derive from a basic philosophical act: the split of the components of the lived experience of the subject with the world" (Castorina, 2002, p. 18, our translation).

These philosophical traditions functioned as a meta-theoretical support (Overton, 2007) for educational practice and scientific research (Castorina, 2020; Winch, 2002). These traditions imply a relationship between worldviews and the concrete practices in which they are revealed. The notion we will use to understand the connection between these macrosocial processes and the emerging concrete meanings is that of epistemic framework (Becerra \& Castorina, 2016; Piaget \& García, 1982). This notion, anchored in the theory of complex systems (García, 2000, 2006), makes it possible to explain how a complex of thoughts permeates a culture, down to its most concrete fields of everyday action. In this way, the orientations imposed by the epistemic framework served as a fertile ground, producing ontological and epistemological assumptions of the modern worldview, projected to our days. Some authors characterized these general orientations under the name of "splitting meta-theories" (Overton, 1994, 2006; Witherington, 2007), highlighting the dissociations to which we refer previously. As a result of this influence on modern and contemporary thought, "[...] psychologists and developmental psychologists, in particular, have considered emotions, sociality and cognition independently of the body, analogous to the software program of a computer that should be studied apart from its hardware" (Overton, Müller \& Newman, 2008, p. 15).

\section{Body-Mind Splitting in Twentieth Century Psychology}

Mind-body dissociation had a remarkable impact on twentieth century psychology. Although there were solid anti-reductionist research programs, it is possible, however, to recognize the prevalence of conceptual models in which the body has no participation in the explanation of cognitive and affective processes (Searle, 2004). In perspectives that go from innatism to empiricism, passing through the discursive currents, the underlying metatheory is that of the split, expressed through multiple dichotomic pairs-mind/body, individual/society, acquired/innate and feeling/reason, among others (Castorina, 2020; Overton, 1991; Overton \& Müller, 2012). The contemporary paradigm that pushed this dissociation to its limits is the one that, in broad terms, we can call "computational theory of mind" and that finds its fundamental metaphor in Turing's machine (Gardner, 1987; Leary, 1994; Searle, 1992). In the mid-twentieth century, this model conceived the mind in analogy with an information processor that works using symbols and rules of storage, combinatory and derivation. In this line, the mind is an abstract representational system, irreducible to the 
biological processes from which it emerges as an epiphenomenon. The acceptance of this assumption was accompanied by a hope that became excessive: that of reaching a precise formalization and mathematization of the processes involved in perception, knowledge production, creation or memory phenomena. Likewise, the promise of parameterization of the computational mind opened the door to the enthusiasts of artificial intelligence and simulation (Haenlein \& Kaplan, 2019; Varela et al., 1991). Indeed, the coherent path for the creation of intelligent devices had to start from a logical and objective description of mental computations in algorithmic terms (Álvarez Hidalgo, 2017; Rivière, 1988).

In this canonical form of cognitivism, in which we find the representational conceptions of the mind, the body played a rather marginal or directly null role (Burdman, 2015). Even though the dependence on a biological basis for the existence of a mind is often accepted, particularly in terms of constrains, in a certain sense, there is a mind-body or mind-brain gap at different levels of phenomena. Mind processes have a specific level of objectivity, normative and operational principles from that of neural and somatic processes, something that permits their analysis with absolute autonomy of the body and its processes. Thus, the ontological and epistemological dualism enables a methodological dualism based on the disconnection of each domain.

This disembodied model of knowledge also led to the invisibilization of a range of diverse ways of knowing, doing and acting, that did not fit into the hegemonic idea of an articulated, objective and universal reason. In a contrary sense, the recognition of the limitations of these models for the psychology of development meant the gradual abandonment of the "banking" conception of the learning process (Freire, 1970, 2006), in which the student receives, in a passive way, a series of truths that pre-exist and transcend him. "In other words, learning is not confined to the heads of individuals, but involves integrating ways of knowing, acting and being within a broad range of practices" (Dall'Alba \& Barnacle, 2007, p. 683).

Since the 1980s, different voices have been raised against the radical dualisms in psychology. These voices attempt to restore a systematic approach and argued that the body has a non-eliminable role in our cognition (Bunge \& Ardila, 1987; Duveen, 1997; Overton, 1994, 1997, 2006; Samuel \& Geoffrey, 1990; Schapiro, 2004; Varela, 1995). These approaches discuss cognitive psychological and dichotomic perspectives and point out the limits of their theoretical orientations (Burdman, 2015). In particular, they highlight the role of the body in general psychological processes (Shapiro, 2014), as well as in formal and informal learning contexts. This allows to avoid falling into some of the varieties of biological reductionisms that developed in parallel in the last half of the twentieth century through neuroscience (Bickle, 2006). The central criticism consisted in pointing out that the characterization of knowledge in the disembodied terms that we pointed out above is insufficient-and sometimes inadequate-to understand the processes of teaching and learning (Benarós et al., 2010). In other words, the critiques showed that it is not possible to ground a valid theory of knowledge-and consequently, about the educational phenomenon-on the model of an asocial, ahistorical and disembodied mind (Teo, 2011). At the same time, an attempt was made to show that knowledge, at any level and without distinguishing between common sense and the scientific rationality, cannot be understood as the result of unanchored, decontextualized computations without values (Gómez, 2014) and genesis (Fox et al., 2009).

There were different ways in which this critique was developed. In one case, a first line built its position through the rediscovery of Vygotsky's cultural psychology, the re-examination of Wallonian and Piagetian dialectical theses on the sensorimotor origins of knowledge (Amin \& Valsiner, 2004; Bergen, 2012; Bidell, 1988; Castorina \& Baquero, 2005; 
Valsiner, 2019; Van der Veer, 1987). A second line followed the propositions in discursive psychology and social constructivism of a dissolution of the mind in the social, from a contextual and relativistic reading-although, consequently, dissolving subjectivity in the field of discourse. Finally, the different systemic perspectives, especially that of enactivism, based on the viewpoint of complex systems (García, 2006), integrated dimensions that had been underestimated or rejected (Álvarez Hidalgo, 2017; Di Paolo, 2013; Holton, 2010; Overton, 1998; Oyama, 1999; Thelen, 2000; Thelen \& Smith, 1990; Valsiner, 1998; Van Geert, 2003; Varela, 2010).

\section{Dichotomies in the Teaching and Learning Processes}

The dualistic background that saturated Western thought had and still has very concrete effects on educational practice. In this context, the very notion of "knowledge" is a key element to understand the conceptual core underlying educational systems. In fact, the characterizations of what knowledge is, how it is acquired, and transformed over time, as well as the question of its origins and conditions of possibility, shape the strategies that are expressed in school designs and teaching programs. And these conceptions about knowledge can be recognized in the educational act itself because in each of these practices there is an answer, explicit or implicit, to the question of the origin of knowledge.

The notion of knowledge as an unanchored phenomenon, in turn, corresponds to a body over which different strategies of domination act. What Foucault (1975) defined as discipline allows us to show how certain social institutions, such as educational establishments, deploy a tacit control over the body, dominating it. Regulated by the mechanisms of surveillance and examination, it is subsumed to the project of the development of disembodied reason. In this way, the biopower (Foucault, 1976) that is exercised in teaching institutions performs a double movement: social control, through which some basic biological functions became the object of a political strategy, on one hand, and the reproduction of a rationality for which the body is a source of noise that must be domesticated, on the other.

In addition, empiricism and rationalism, to which we refer schematically above, are two broad streams organized precisely around the problem of human knowledge and learning. These questions flourished in several fields and oriented the conceptions of what a teacher and a student are, and the type of social performance that should be established between them. In the concrete sphere of the classroom, those theoretical solutions on how one knows and how one transforms knowledge were guides for the design of teaching activities and practical strategies in general. From descriptive and teleological innatism to environmentalism (Foucault, 1957; Valsiner, 2017), each model left its mark on modern schools, in the configuration of the physical spaces in which teaching takes place and also in didactics and pedagogy. These same orientations can be found in the sociological aspects of education (Ignatow, 2007), or in the history of pedagogy (Compayré, 2015), always with an incessant alternation between polar solutions.

Following Molander (2009), there are five definitory aspects of the traditional conception of knowledge in the Western world: (i) the acceptance and use of dichotomic pairs to express the problems around knowledge-subject/object, mind/body, innate/acquired-inherited from "the philosophies of split"; (ii) the distinction between abstract knowledge and applied knowledge; (iii) the assumption that knowledge can-and must-always be formulated in words or expressed in the language of mathematics; (iv) the characterization of knowledge as a reflection or copy of objective reality; and (v) the assumption of eternity and universality of the current knowledge. As a whole, these five points are the general 
matrix from which the educational strategies of the last two centuries were designed. Each of these statements presupposes "that there is a pure form of knowledge with a single goal: to understand". Briefly, "[...] knowledge is in the subject, in a symbolic form, which can be made explicit (be externalized) by means of a mirroring (a re-presentation) of reality (the object)" (Molander, 2009, p. 58).

In addition, the schema critically drawn up by Molander seems to be promoted by current educational policies and worldviews on education. In particular, within the so-called neoliberal ideological framework that guides a large number of contemporary economies (Nedbalová et al., 2014). The phenomenon identified as "marketization of social relations" characterizes social subjects and interactions in terms of a prevailing neoliberal economy (Molesworth et al., 2011; Puiggrós, 2017). This orientation of the actions facilitates the reproduction of dichotomic logics. The promotion of "creativity", "meritocracy" and also the definition of the educational act in terms of "entertainment" reinforces the conception of an ahistorical subject, decontextualized and, moreover, unilaterally responsible for the successes and failures of the process (Marshall, 2017). In these movements of the meanings, the student is seen as a user, the teaching process as a service offered to the client, the learning process as an act of consumption and the pedagogical strategies as a show. This approach leaves in the shadows the complexity of the social and dialectical encounter that occurs in the teaching and learning processes.

These macro-matrices, which regulate social practices and thus emergent meanings, have consequences for the way in which subjects conceive their own experience. More specifically, the general frameworks intervene in the way subjects perceive and describe their experiences, on the basis of categories that culture presents as radically dissociated. The sharp division between body and mind is offered as a semiotic support for reading experiences and representing the different activities. This is why, as several studies show, educational practice and other social institutions that reduce the body to the role of a mere vehicle or, more radically, to that of an interference that must be controlled (Turner \& Turner, 1992), promote individual experiences of dissociation (Rodó \& Saball, 1994). Disciplinary strategies have effects on the ways in which subjects navigate educational institutions, and the exacerbation of dichotomous logic reappears at the individual level under the experience of a division (Scharagrodsky, 2007). In other words, institutional logic reappears in the individual representations, and this is why we are interested in the institutional organisational models and shared cultural meanings.

The recognition of these phenomena led to a number of serious questions. The criticism of dualisms that was expressed during the twentieth century in the arenas of philosophy and psychology also had its correlate in the considerations on teaching and learning: "[...] in the current socio-political climate, pedagogies consistent with rationalism are in the ascendancy. One way to challenge the purchase of rationalism within educational discourse and practice is through the body, or by re-thinking the nature of mind-body relations" (Barnacle, 2009, p. 22).

Although the notion of embodied mind is polysemic, it constitutes a challenge to traditional thinking (Lakoff \& Johnson, 1999a, b). The multiplication terms with slightly different meanings, "such as situated embodiment (Zlatev, 1997), mechanistic embodiment (Sharkey \& Ziemke, 2001), phenomenal embodiment (Sharkey \& Ziemke, 2001), natural embodiment (Ziemke, 1999), naturalistic embodiment (Zlatev, 2001), social embodiment (Barsalou et al., 2003)" (Ziemke, 2003, p. 1305), seem to show a fragmented and inconsistent field. Among other reasons, it seems that there is no agreement on the very notion of body. 
Given this polysemy, there are two possible strategies to arrive at an answer. First, following the usual paths, it is possible to adopt, in an argumentative way, a definition of body and then use it as a theoretical analytical tool. In this article, we will follow another path: we will try to identify the original and contextualized meanings about the body emerging from the analysis of student's diaries (Moon, 2006). More precisely, we will seek to contrast two matrixes of meanings: those of the philosophical, psychological and educational traditions that we mentioned above, and those that emerge from the students' experiences, as reported in their personal diaries. This implies that we will not be looking at bodily interactions, but at the awareness or conscious need of lived experiences (Ferreiro, 2001; Piaget, 1974), reported through the diaries. In this way, the meanings about the body found in the diaries constitute for us a particular matrix of meanings, which, however, cannot be read outside the epistemic framework (Abbey \& Valsiner, 2004; Castorina, 2020; García, 2000).

To do so, in the next paragraphs, we will present the analysis of two innovative university-level courses in which the body had a central place, mainly using performing arts. Focusing on students' own perspectives, we will formulate some emerging hypotheses, consistent with our theoretical perspective (Valsiner, 2007, 2013) to define the perimeter of this field of phenomena that we will call situated body.

\section{Re-engaging the Body in Higher Education: the ASCOPET Research Project}

\section{The Courses Under Analysis}

What happens, then, when the body is put back at the core of the pedagogical experience? Our data has been collected during the development of two non-conventional universitylevel courses in which, through improvisation and theatre, the body plays a radically different role from what would traditionally be expected in these educational settings.

The courses under analysis were Improgineering (École polytechnique fédérale de Lausanne) and Psychology and Migration (University of Neuchâtel). They are both elective courses at the Master and Bachelor levels, from two Swiss universities. One for students in engineering, the other for students in psychology and education. Improgineering examines the creative processes in science, engineering and the performing arts. During the first semester, workshops explore improvisation in the performing arts. Additional lectures cover the dramaturgy and sociology of improvisation, improvisation in engineering and creativity in science. During the second semester, students work in groups towards an improvised performance based on physical artifacts that they have created. As a final step, students have to present a 12-min performance on stage at the Arsenic Theater (Lausanne), with the only condition of having to put on stage the artefact created during the course. On the other hand, Psychology and Migration introduces students to a sociocultural approach of the psychological aspects involved in migration. After a first module with theoretical content, students begin a group work phase. The objective is to make a short theatrical presentation of 5 to $10 \mathrm{~min}$, based on a literary work that addresses the phenomenon of migration. The final presentation takes place in "Le Lokart", a local cultural space.

These courses differ in the target group of students, main topic and curricular design. But they share some characteristics, like the use of performing arts, the focus on collective creation or the occupation of non-university spaces. In fact, performing arts shape part of 
the teaching strategies, giving its logic, its principles and a specific dynamic to the interactions. In this sense, they are distanced from traditional formats, both in terms of curricular planning, promoted activities with students and validation criteria, as well as the physical and symbolic spaces in which they are carried out. However, the originality of these pedagogical devices does not lie in the use of theatre and improvisation as simple mediators in the general educational setting, in the way of an atypical resource or instrument to achieve certain educational goals. In other words, the courses are not conceived following a traditional format to which an artistic dimension was later added as a facilitation to express or translate contents, nor is it a mere expansion of the standard educational horizon or an enrichment of experience through the inclusion of an "aesthetic window" or a "bodily dimension" of the activities. As a whole, both proposals are organized around a logic of knowledge production that fully redefines the field of possible interactions.

This redefinition can be seen at diverse levels. Firstly, the orientation acquired by learning is neither anticipated nor intentionally directed by teachers towards certain contents or expected knowledge. The courses are generally framed with some structured activities and a pedagogical contract-which includes confidentiality and respect-but without rigid prescriptions. Within this perimeter, the students choose the way in which they will work, and the role of the teachers is not to judge the distance of the intervention from an expected competence but to coordinate and promote interactions, collective activities and engagement with the topic of the course, without imposing a hierarchy of authorized voices. This freedom and the continuous negotiation among the participants define a way of teaching, learning and dealing with contents. At the same time, it is a way of moving to "expertise", conceived as collective, flexible and expansive activity (Engeström, 2018).

Secondly, knowledge is not anticipated as contents to be taught, and the outcome of the process is not predictable, nor does it imply a development with phases of increasing understanding. Since there is no standard and established knowledge-objective, the path of each student is unique and cannot be adjusted to a criterion of collective homogenization: not everyone is expected to arrive at the same point, nor is it possible to establish a hierarchy of the experiences obtained.

This, in turn, has immediate consequences on the form that the evaluation takes place. Cumulative or formative evaluations, understood as corroboration and pondering of certain notional or attitudinal acquisitions, lose all sense. Evaluating, in these curricula, consists of verifying that the student can show certain relationships between practices of diverse spheres of the daily life experience-emotional, analytical, personal, familiar, communal, social, scientific, artistic, etc. It also means to analyse if they can use the proposed activities as a platform for reflection as well as to gain some experience in the field of the course. Consequently, evaluations are based on two key instances: for Improgineering, the written reflections on the student's own experiences in a so-called "reflexive diary", and the final presentation on the stage; in the case of Psychology of Migration, only the personal "learning diaries" are evaluated, as well as the participation and engagement during the course, until the final theatrical performance.

\section{Data and Methodology}

In order to analyse the two courses described above, the procedures for data collection in the ASCOPET research project aimed at being as similar to each other as possible. To construct the date set, we conducted in 2018 and 2019, (a) a documentary analysis (explicit 
administrative references and curricula of the two courses); (b) ethnographic observations (including observations during the courses, observations of some volunteer students' groups in and outside the university, during the preparation of the courses, and observations of the feedback sessions); (c) interviews (individual and collective interviews with teachers, individual interviews with some volunteer students, focus groups with some volunteer students at the end of the course); and (d) a systematic analysis of the students' personal diaries ("learning diaries" and "reflexive diaries"). For the qualitative content analysis of the sources (Elo \& Kyngäs, 2008; Krippendorff, 1980; Mayring, 2004, 2019), we create a set of 49 categories (Mayring, 2015) distributed across the following 7 dimensions: (a) knowledge production logics, (b) students' perspectives, (c) teachers' perspectives, (d) collective work, (e) embodied activities and body role, (f) meta-reflection and grasp of consciousness, and (g) modes of communication. As a first top-down data reduction strategy (Rodríguez Gil \& García, 1996), we use these categories to code the data, in their various sources, using MAXQDA, a software for qualitative data analysis. The coding of the qualitative material resulted in 1308 segments, among which approximately 500 are dealing with the bodily dimension of the courses. After mapping the recovered segments, we performed a reconstructive process (bottom-up) and a methodological triangulation (Vasilachis de Gialdino, 2006), to identify recurrences, associations, inconsistencies or contradictions.

These data were examined during our internal team workshops, which bring together some teachers from both courses, as well as the educational and artistic researchers. Our preliminary analyses highlighted the specificity of the bodily experience that these courses imply, and the connection of this bodily dimension with other aspects of the courses (including collaboration, personal accountability and engagement or transformation in students-teachers relations). In this paper, we will discuss only one topic (the body in the experience of the course) and one perspective (students' perspective) based on one source of data (the learning and reflexive diaries). For this, we collected 47 diaries (22 for Psychology and Migration and 25 for Improgineering), and we used the mentioned procedure for categorized text and visual materials.

We must point out that diaries are a key pedagogical device in both programs. Written during the development of the courses, they form the basis of the final evaluation and, consequently, teachers are their main addressees. However, some students wrote the diaries for themselves or having other explicit recipients in mind; so, they asked for them after the evaluation process was over. At the starting point, students were asked to write their diaries weekly, and few additional instructions were delivered: they were only told that (a) they were free to write the diaries in the form they like, that they could write an electronic or handwritten report, using drawings, paints or whatever other form they wish (freedom of form); (b) they should not "go back" and erase past entries but add new ones, if they change their mind; (c) they should deliver the diaries on time (at the end of the semester for the Psychology and Migration, and at four different moments during the year, for Improgineering). The lack of formal instruction regarding content makes the diaries a space of freedom for the students, which is usually uncomfortable for them but mirrors the logics of the courses. The diaries become a factual trace of their experiences and reflections linked to the course, materializing their personal path into the proposed activities. Interestingly, the experience of the body described in the diaries is not only the experience lived in the course, but this lived experience; it was reconstructed later and reedited through the writing of the diary.

The next section presents some results of our systematic qualitative analysis of these diaries along the dimension of the body. We took all the codes related to the body (or 
bodily engagement, embodied action, etc.), and we reconstructed matrices of meanings on this subject. We will organize the presentation around five points: (1) communicating bodily experience in diaries: historicization and multimodality; (2) thematic modulation, (3) spatial modulation, (4) the body as a bridge to others and to oneself, and (5) the body as a condition for biographical continuity. Through this arrangement of data, we will try to show the emerging meanings on the body, in the context of both analysed courses. In this sense, what we present in the next section is the end of a reconstructive analytical process. First, we sift all the textual and visual materials from the diaries through the categories of analysis, and then, from these minor elements, we reconstruct the matrices of meaning about the body. However, to illustrate some of the generalizations, we will use concrete examples. The quotations from texts and images that we will use only have the function of illustrating a generalization that we arrived at by observing systematic recurrences between the different diaries and between the textual and visual modalities.

\section{Findings}

\section{Communicating Bodily Experience in Diaries: Historicization and Multimodality}

The range of formats and materials used in the diaries was remarkably variable, both in content and form. Diaries are multifunctional because they constitute a support for mediating the experiences. They are also a private way of communicating ideas and feelings that in the context of the class are not usually shared. Finally, they are an opportunity to reconstruct the experiences of each student, using semiotic resources that are qualitatively different and displaced in time. In this section, we will consider three sub-topics: the function of the recipient of the diary in the development of one's thinking on the body, the process of historicization of the bodily experience through its inscription in the diary, and multimodality and what it says about the kind of experience students attempt to convey.

Firstly, diaries are a type of artifact, that is, something made by the student considering-consciously or unconsciously-an other: a recipient. That target, manifest or implicit, is not always the teacher who will finally receive the diary. In fact, while some diaries mention teachers explicitly, as if they were talking to them, others just give an account of an internal reflection which, through certain resources, gets material status. This dimension of the recipient of written production has been studied by several authors in the context of literary production. For example, punctuation is fundamentally a set of instructions for the reader, and its absence and subversion bring the writing closer to the flow of thought or free association (Ferreiro et al., 1996; Ferreiro, 1997). In this sense, the way in which punctuation is used and the contents are spatially distributed, bringing the subject closer or further away from the potential reader. At another level of language concreteness, the formal structure of the text, with headings, closures and explanatory segments, also accounts for a potential reader. In the analysed diaries, these potential readers were basically of three types: (a) the teachers; (b) the subjects, in a sort of internal dialogue with themselves; and (c) the diary, as an abstract recipient. Examples of the first case can be seen, especially, in the opening and closing of the text, with the explicit mention of the teacher-readers or through certain complaints or acknowledgements for what happened during the class. In this case, teachers become the addressees of a certain attribution of responsibility. This is a case in which the diary makes "the other" consistent and at times so real that he/she can be attacked or celebrated. In the other two situations-that of those who use the diary to express something not 
clearly addressed, or that of those who start their writing using the formula "dear diary..." -the existence of the other is diffuse. These are different modalities, ranging from the invocation of a known presence to a much more abstract use of relationships with others. Within this spectrum, we can identify certain variations with respect to the way each one demands and calls for the support of a body to think about his or her actions. This is a first approach to the dimension of the body: thought seems to be directed and organized differently if the recipient is "embodied" in a particular person. In these cases, it is the body of the other subject that intervenes in the composition of one's thought. When the "other" in the diary is disembodied or abstracted, the contents become much less limited.

Secondly, the diaries have a double temporality: they keep trace of the past subjective experiences of the course, reflected and refracted at the moment of the writing of the diaries. As we said, the diaries were produced after the course; so, they do not refer to the experience lived at the time of their production, but to the experience of a past class. At the same time, they were produced outside the space of the course, showing a double displacement, in time and space. This gap seems to be the condition of possibility for students to establish bridges between the symbolic and material space of the classroom and everyday life, a connection expressed by the series of meanings that explicitly give an account of a resonance. On several opportunities, students mention in their diaries' previous experiences-some very remote-associated with the activities of the course. In other words, the diary function as bridges between biography and the experience raised in the course, as we can in the following examples:

\section{Box 1. Communicating Bodily Experience in Diaries: Historicization}

J'ai été intéressé par l'atelier car j'ai déjà participé à plusieurs ateliers d'improvisation de piano et également dans des ateliers de jazz. J'aime beaucoup la démarche improvisé et l'écoute qui est nécessaire de mettre en place. Venant de la musique, je n'ai pas d'expérience théâtrale et je m'inquiète un peu car je suis plutôt de nature timide. (Reflexive diaries_Impro).

II was interested in the workshop because I have already took part in several piano improvisation workshops and also in jazz workshops. I really like the approach of improvisation and the listening that is necessary to put it in place. Coming from music, I have no theatrical experience and I worry a little because I am rather shy by nature].

Lorsque les mouvements devinrent plus libérés, qu'on avait le choix de l'abstraction, je me suis surpris à effectuer des mouvements appris en athlétisme. (Reflexive diaries_Impro).

[When the movements became freer, when we had the choice of abstraction, I was surprised to perform movements learned in athletics].

Thanks to this bridging function, the bodily experience of the course, i.e. the sensory and motor experience of the body in context, can be related to other experiences and situations. The diaries facilitate and promote the integration of the course experiences into the subjects' biographies. In particular, the "second experience" that takes place through the production of the diary seems to be a condition for the embodied experiences to be linked to other bodily experiences, through the establishment of a series of events. And of course, this process is neither spontaneous nor automatic. In this sense, the diary operates in the 
body a process of historicization. The experience of the body is inscribed in the biography and acquires temporal thickness.

Thirdly, a central feature of the diaries is the importance of multimodality because it provides a multimodal reconstruction of the experience. In our sample, in addition to narratives, we find not only 423 images, drawings or photographs, a hundred quotations-most of them from literature or poetry-but also handcrafted objects like a wooden mini-theater, and some videos and music.

\section{Box 2. Communicating Bodily Experience in Diaries: Multimodality}
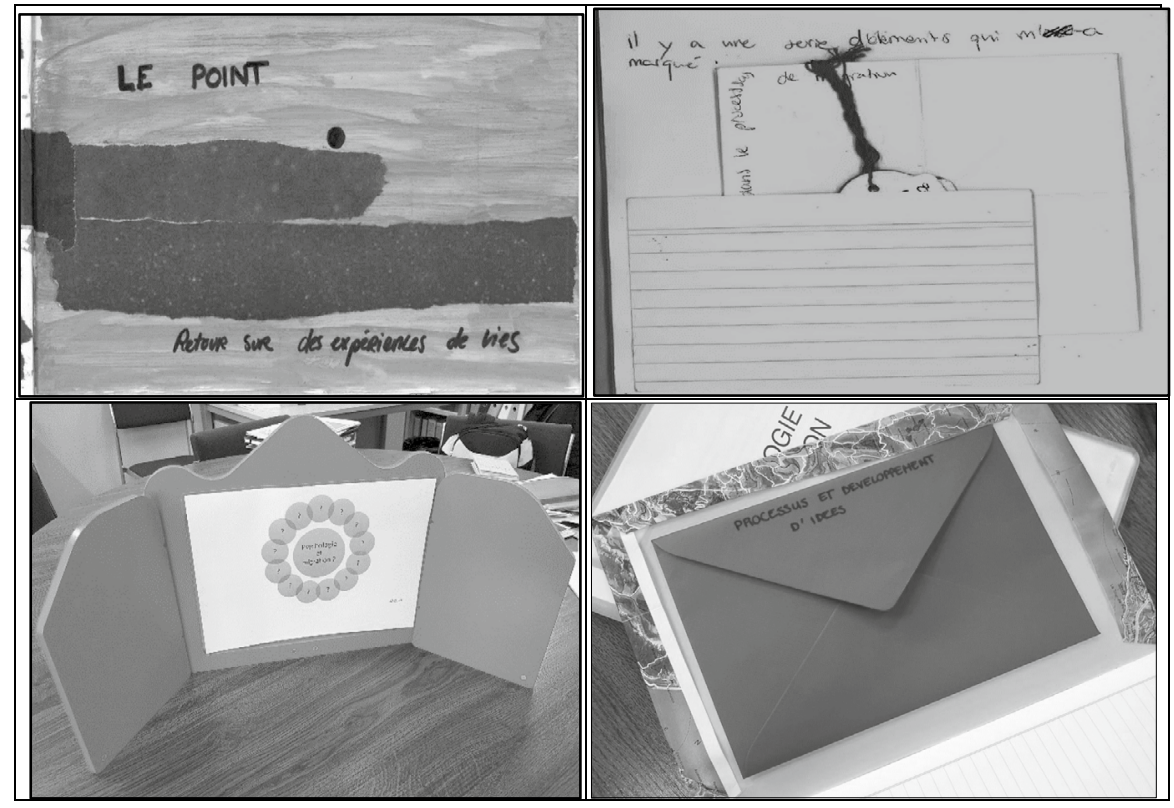

On the one hand, the various ways and means by which students communicate in their diaries are not simply equivalent and mutually convertible interfases. In other terms, they are not different channels for the same message, because the channel is partially the message-to rephrase a basic thesis of Watzlawick's communication theory. The variety of resources used to "register" an experience in a diary seems to show the insufficiency of traditional language and organized narrative to communicate some experiences, especially emotions and body sensations. The experience of and with the body leads to the choice of multiple supports to communicate or establish them materially. 


\section{Box 3. Communicating Bodily Experience in Diaries: Multimodality and Layers of communication}

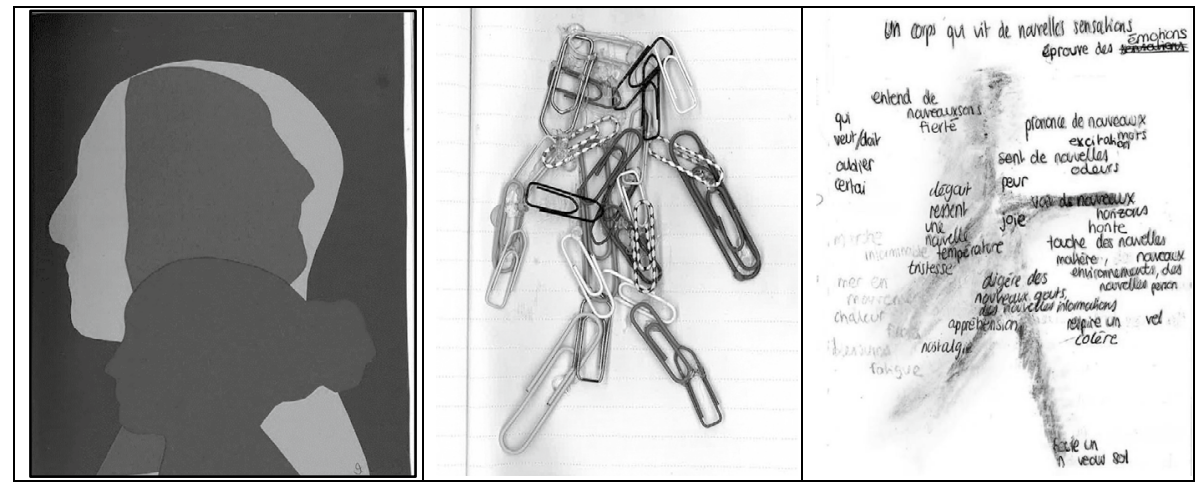

On the other hand, it is not possible not to communicate (Watzlawick et al., 2011). In the diaries, everything seems to be a message because everything is potentially readable. From the general framework established by the pedagogical contract and the deadlines for the diaries, even absences can be considered communications. Some images or resources that do not seem to be legible, in the context of the diary, acquire a possible meaning, as is always the case in the reader-author dialectic. A dot or a blank page can be meaningful if they are articulated with a chain of signifiers. Even not presenting the diary in one of the fixed instances is a way of evasion that can be read in the general framework of the course and other layers.

In this dynamic, it is possible to recognize some of the ineffable dimensions of the experience with the body: the alternation presence/absence, pleasure/displeasure, and joy/anguish, among others. Recognizing that it is not possible not to communicate, we must pay attention to all those elements that in a context of discursive analysis would remain unnoticed. With respect to our focus on the body, we believe that this is precisely a dimension that we should privilege if we wish to focus on the specific meanings around the body that emerge in these educational contexts. The multimodal aspect of the diaries facilitates the integration of experiences of different order. Diaries allow students to mediate thought, not only by language of conscious narrative but also by sensory, poetic or ineffable expression, through colours, textures, music or images. Although language is the most extended system of signs and the only one able to act as a metalanguage of itself (Greimas, 1973; Samaja, 2006), the "translatability" between the different modes always implies losses or transformations. The intimate experience of touch or hearing can only be contoured and never captured by language. Moreover, collage, mixing text and drawings, making use of maps or even music, makes it possible to express fragmented, hybrid or tense experiences. These different modes of communication act as shortcuts to the materialization of an experience, but they also make possible to account for the complexity of the experience through the density of the different layers of communication.

In other words, the multimodal production is a support for the awareness, not only of what belongs to the field of argumentative reason but also of other experiences that would otherwise be lost or invisible. Enabling the use of resources of different order facilitates the representation of ambiguity, contrasts, overlapping or fragmented feelings or ideas, all inherent aspects of the lived experience, which are often actively rejected by the argumentative logic privileged in academic settings. If diaries allow us to approach the experience around the body that students have, it is precisely because they succeed in grasping specific dimensions of the sensory, perceptual and emotional levels. 


\section{Thematic Modulation}

Comparing the diaries from both courses, we notice that the general subject of each of them modulates the awareness of the body. In other words, the topics covered by the course emphasize certain representations of the body and a particular insight of its multiple aspects.

Psychology and Migration is not only a course that deals with the subjective experience of migration, linked to current topics present in everyday media, like mental health of refugees, but is also connected to daily life experiences of the migrant students. These topics seem to have functioned as a ground on which to represent and think on the body. Thus, the explicit representations that can be found in the learning diaries often refer to the finitude, pain or fragility of the human organism. The subject of death also emerges repeatedly, in the texts and images. In general terms, the body is represented from its vulnerable side.

\section{Box 4. Thematic Modulation}

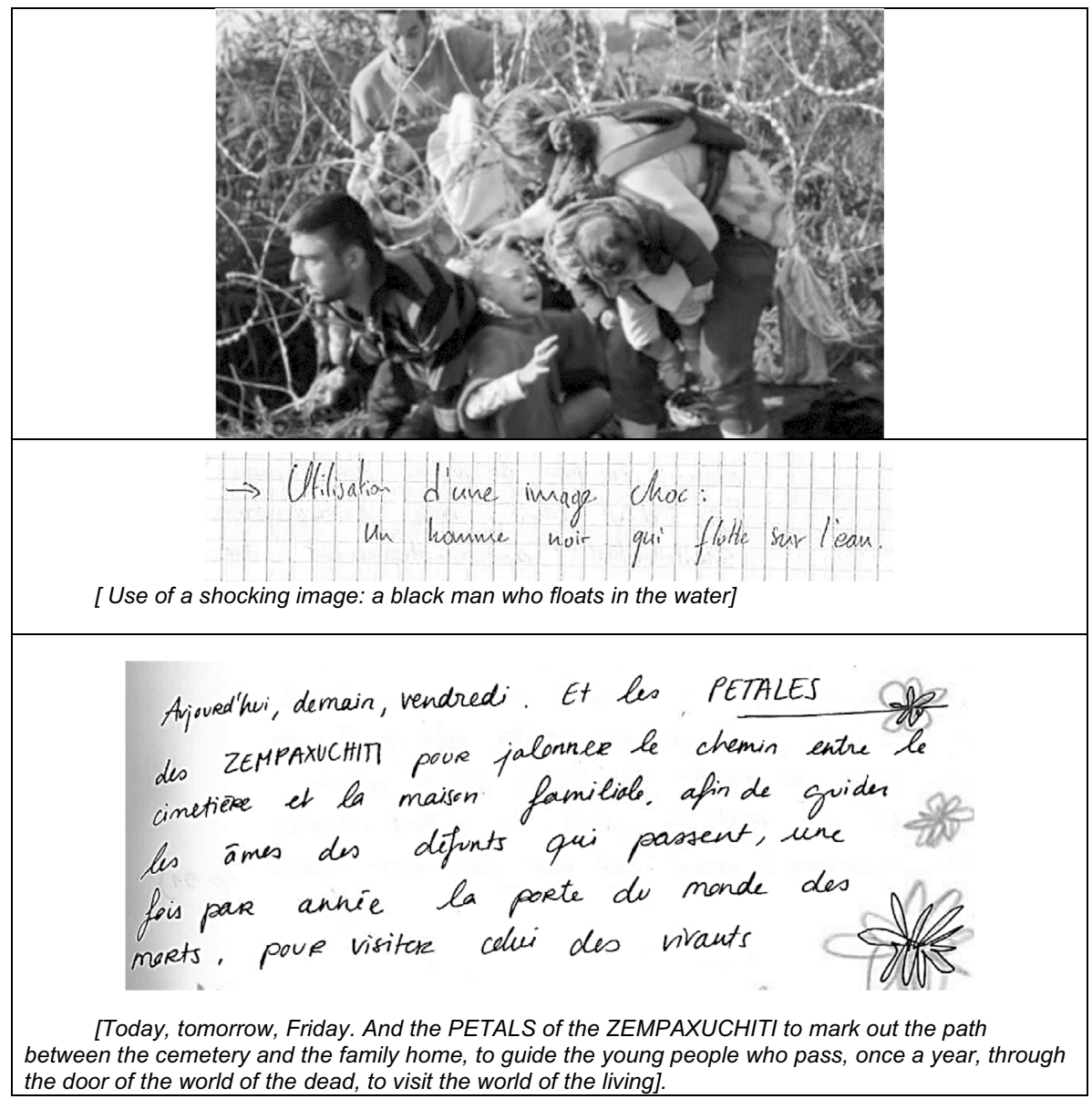


In turn, in the course Improgineering, the thematic core is not only improvization and collective creation, from the perspective of disciplines such as theatre, dance or music but also sociology, mathematics or anthropology. In this case, allusions to the fragility of the body are almost non-existent in students and teacher productions. The bodily experience appears to be constantly linked to the creative process of the group, to the encounter with sensations and emotions or to the availability to act in response to the requests of the others. In accordance with this meaning bias, the characterizations of the body made by students in their reflexive diaries are insistently not only referred to a seat of pleasure, amusement and enjoyment but also of fatigue, tension or stress. In this case, the kind of sensitivity that becomes evident is guided by the activities and topics of the course, which function as attractors (Valsiner, 2018).

\title{
Box 5. Thematic Modulation
}

\begin{abstract}
J'ai beaucoup aimé la métaphore du corps comme un voile qui oscillait aux courants de l'air, sa permettait de se relâcher de se laisser porter par les deux autres, d'être sensible aux forces qu'ils imposaient, d'avoir du détachement. Plus difficile qu'il n'y parait d'être détendu au niveau des chevilles tout en gardant une certaine tenue du corps. (Reflexive diaries_Impro).

II really liked the metaphor of the body as a veil swinging in the air streams, allowing you to relax, to let yourself be carried by the other two, to be sensitive to the forces they imposed, to have some detachment. It was more difficult than it seemed to relax at the level of the ankles while keeping a certain body posture].
\end{abstract}

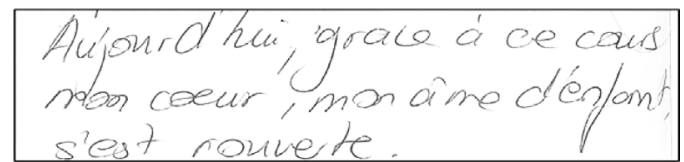

[Today, thanks to this course, my heart, my infant spirit, has reopened].

The main meanings are different in both courses. The type of body that is "called" in each one differs, fundamentally because of the symbolic mediations and the topics with which they are connected. The meanings of the body are contextualized and mediatized reconstructions, carried out in two times: at the moment of the lived experience and at the moment of the production of the diaries, with the bias imposed by the semiotic resources provided by each course. This interpretation is consistent with the notion of a body in constant evolution, without a clear and fixed entity and identity. The cloud of meanings around the body has fuzzy boundaries, expanded and contracted in accordance with the available mediations and the relationships established by the main subject. In a word, we can argue that, in an educational context, these thematic modulations actively trigger bodily perceptions and representations in guided directions.

\section{Spatial Modulation}

The topic of space is highly present in diaries and frequently connected to the bodily experience, as we can see in the following quotes. 


\title{
Box 6. Spatial Modulation
}

\author{
On apprend à voir l'espace. On apprend à mettre son " soi " à distance. (Reflexive \\ diaries_Impro). \\ [We learn to see the space. We learn to put our "self" at a distance]. \\ L'échauffement qu'A. nous fait faire, est absolument parfait, j'en ressors pleine d'énergie et \\ prête. C'est une piqure de rappel qui vient à point pour nous rappeler la présence de nos corps \\ dans l'espace et en relation avec les autres. Ça me permet de me concentrer. (Reflexive \\ diaries_Impro).
}

[The warm-up that A. makes us do, is absolutely perfect, I come out of it full of energy and prepared. It's a gentle reminder that comes just in time to remind us of the presence of our bodies in space and in relation to others. It allows me to concentrate].

On a appris à se concentrer sur nos mouvements, la position de de nos membres, et ce que cela pouvait signifier. Travail sur la proprioception et l'extéroception. En effet, essayer de reproduire des mouvements du quotidien sans qu'il n'y ait le contexte pour celui-ci nous force à chercher : " comment je réalise cette action ? " et ainsi nous replonge dans cette action et son contexte. On devait reproduire le fait de cueillir une pomme, de la manger puis ensuite de s'allonger au sol, action qui sollicite ainsi l'ensemble de notre corps. Tout cela toujours en mouvement dans un espace. (Reflexive diaries_Impro).

[We learned to focus on our movements, the position of our members, and on what it could mean. Worked on proprioception and exteroception. Indeed, trying to reproduce everyday movements without the context for it forces us to explore: "how do I perform this action? "and therefore, we plunge into this action and its context. We had to reproduce the gesture of picking an apple, eating it and then lying down on the ground, an action that demands the whole of our body. All this always moving in a space].

We would like to highlight the way in which different dimensions of the bodily experience present in the diaries are connected to space: firstly, to a safe space (Rom, 1998), which is in part a consequence of the pedagogical situation; secondly, to a material and symbolic space, conceived as different from the traditional academic spaces. As we will see, these two dimensions are interconnected.

At the beginning of the diaries, the students usually describe the uncertainty about what was expected of them, both in the course and in the production of the diary itself. This is a typical question about the role to play, about what is expected from them and, therefore, about the definition of the place of the student. These concerns give an account of a series of expectations and of the attempts to make compatible a "student ethos", instituted in the formal educational establishments, and the dynamics that these courses impose. Inconsistencies quickly appear in the diaries and are expressed through surprise or rejection about the type of practices proposed in class. "What is all this about?" this uncertainty about the social role in the microculture of the classroom is translated into expressions of discomfort or awkwardness. But once students move on and discover the logic of the encounters, that anxiety is dissolved. The data show us that this passage is directly linked to the configuration of a kind of "safe space". To be able to deal with a course in which the demands are deeply different from others, it is essential to achieve a change of position. The safe space to which we refer is precisely the result of the recognition of a possibility to act without being judged, condemned or without their acts being the object of some form of "instruction". In the constitution of this safe space, we observed key aspects, among which mutual social recognition and horizontality of relations are fundamental. In the diaries, we found frequent references to the fact that, unlike other courses, teachers are involved in activities together with students. Everyone participates in the exercises and reflections, without reproducing any kind of hierarchy. 
Additionally, the space of the body is also the material space, with its symbolic dimensions. Both courses were held totally or partially outside the university buildings-in a public theatre or community rehearsal room. Within these spaces, the material disposition is evidently different from that of the university. First of all, the traditional classroom structure does not exist. There is no blackboard and chairs oriented in the same direction, to mark the teacher/student asymmetry. The lighting, the furniture, and the common spaces outside the classroom are also signs of a different regulation. The logic of the university is not omnipresent at this level, and students adopt other norms and ways of acting, because the uses of the body, clothing and the way they inhabit space are conditioned, in part, by their material organization. As a result, we observed that the uses and representations of the body are influenced by the real spaces-material and symbolic-in which the courses are inscribed. Briefly, the body is a situational effect.

\title{
Box 7. Spatial Modulation
}

\begin{abstract}
Premier réflexe que j'ai eu en entrant dans la salle : enlever les chaussures. (Reflexive diaries_Impro).

[First reaction I had when I entered the room: take off the shoes].

Quand on danse, la notion d'espace se remet en question, la danse fait penser l'espace en fonction du corps, de son mouvement, et de ses interactions avec d'autres corps. C'est un peu comme l'architecture, ces deux arts ont pour but de faire évoluer le corps dans un espace. Peutêtre que lorsqu'on danse, d'une certaine manière, on est aussi architecte inconscient. L'architecte façonne l'espace, le modèle comme de la pâte à modeler, pour créer des interactions. Lorsqu'on danse, on crée des compressions, on se dilate en l'aggrandissant (souvent quand je faisais du ballet, on me disait de tirer mes bras comme si j'avais des bras infinis), on retient son souffle, on crée des tensions. Ça me rappelle les sculptures de Richard Serra, qui compriment l'espace ou l'étendent selon ou on se place. (Reflexive diaries_Impro).
\end{abstract}

[When we dance, the notion of space is questioned, dance makes us think about space in relation to the body, its movement, and its interactions with other bodies. It's a bit like in architecture, these two arts aim to make the body evolve in a space. Maybe when we dance, in a way, we are also unconscious architects. The architect shapes the space, models it like plasticine, to create interactions. When we dance, we create compressions, we expand by enlarging it (often when I was doing ballet, I was told to pull my arms out as if I had infinite arms), we hold our breath, we create tensions. It reminds me of Richard Serra's sculptures, which either compress space or expand it depending on where you stand].

Nous nous retrouvons pour la première fois au théâtre de l'Arsenic. C'est une bonne chose d'être en dehors de l'Epfl. Changer de cadre. Ce cours promet d'être différent, une bulle d'air, je l'espère. (Reflexive diaries_Impro).

[We meet for the first time at the Arsenic Theatre. It's a good thing to be out of the Epfl. To change backgrounds. This course promises to be different, a bubble of air, I hope].

L'Université c'est plutôt être assise toute la journée sur une chaise à écouter des théories pas toujours intéressantes, alors je crois, que là au milieu, un cours où l'on peut s'exprimer plus librement, par le corps, en petit groupe ça m'a attiré. (Learning diaries_P\&M).

[University is mostly about sitting on a chair all day listening to theories that aren't always interesting, so I think a class in the middle where you can express yourself more freely, through your body, in a small group, attracted me].

Nous voilà au Lok'art. Première action dans ces lieux : retirer nos chaussures. C'est bien pour moi synonyme de liberté. On est si bien pieds-nus. Un peu pour moi le fait d'être d'égal à égal. Aucun talon qui nous place en dessus ou au-dessus de l'autre. (Learning diaries_P\&M).

[Here we are at the Lok'art. First action in this place: take off our shoes. That's good for me. It means freedom for me. We're so comfortable barefoot. For me it's a little bit like being equals. No heels that put us on top of each other or above each other]. 
The space in which the students deploy their actions intervenes in the definition of the limits of possible actions. The logic and the norms attributed to space define, as a continent with its limits, the possible actions, and the body and its uses are contextually transformed. Consequently, one way in which university logic can be subverted seems to be, in our cases, the migration towards spaces conceived for other types of interactions.

As a preliminary conclusion, the creation of a safe space is crucial for the understanding of the body in context, because sensitive and expressive possibilities depend on it. Being "barefoot" or on the floor "breathing", as mentioned by some students, allows a particular perception of the experience. The body that emerges here is one with a sensory quality that has almost no place in traditional academic spaces. In short, the definition of a safe space for action, beyond censorship, enables the emergence of a typically denied body. Following this hypothesis, it is possible to argue that body and space are two poles of an indivisible dialectical dimension.

\section{The Body as a Sensitive Bridge to Others and to Oneself}

Engaging the body is a way to call up emotions and feelings. The body does not express itself only in its spatial dimension but through a specific affective sensitivity. To introduce the body into the teaching and learning processes is to promote the emergence of some kind of awareness of the affective level and the consequences of this. The body/emotion relationship is evident for students and they express it in their diaries. However, this relationship, which is expressed as a form of contact, or sensitivity to contact, with affective marks and tones, has two directions. On the one hand, we find a large number of references to communication with others, through the sensitivity of the body or of the emotional resonances that the contact with others generates. On the other hand, we find allusions to the recognition of a personal and embodied dimension of experience, where the bodily sensitivity and affective tones is also the condition of emergence.

(a) Body as a way to get in touch with the others

\section{Box 8. Body as a Sensitive Bridge to the Others}

Nouvelle salle. C'est grand. C'est grand, mais l'intervenante a délimité l'espace. On déambule, on marche, lentement, vite, à nouveau lentement. Ces exercices me mettent inconsciemment à l'aise, c'est un premier exercice qui nous met tous en contact de manière progressive. (Reflexive diaries_Impro).

[New room. It's big. It's big, but the facilitator has delineated the space. We move around, we walk, slowly, quickly, slowly again. These exercises put me unconsciously comfortable, it's a first exercise that progressively puts us all in contact].

Lors du cours d'introduction, j'avais déjà senti cela dans la salle. Des regards laissant deviner quelques poésies, quelques éclats de singularités palpables. J'ai pu ressentir, parce qu'on avait le temps, la posture aussi et la disponibilité, l'attention de chacun envers les corps, les regards, les interactions en tous genres. (Reflexive diaries_Impro).

[During the introductory course, I had already felt this in the room. Glances that suggested some poetry, some glimpses of palpable peculiarities. I could feel, because we had the time, also the posture and the availability, the attention of each person to the bodies, the gazes, interactions of all kinds]. 


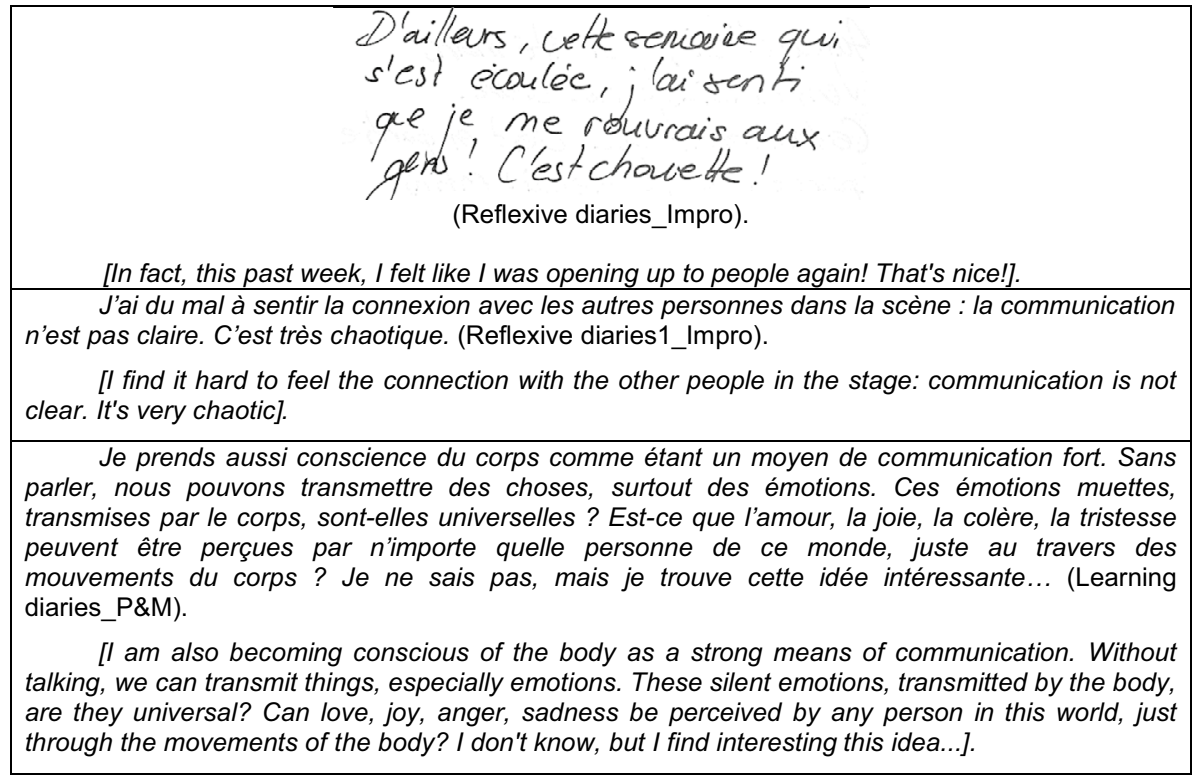

(b) The registration of one's own body.

\section{Box 9. Body as a Sensitive Bridge to One's Own Body}

Sur scène, j'ai ressenti, en vrac : mes mains, mes jambes, le déplacement animal, un peu de sauvagerie, les connections très intime, seulement partagées avec une ou deux personnes. Et quand de la distance se créait, parce que parfois on ne se comprenait pas, j'ai trouvé qu'on créait des ruptures intéressantes. Un peu fragiles parfois, je n'étais pas trop sûr de ce que j'étais en train de faire, mais je testais, j'oubliais le regard des autres dans l'urgence d'en trouver un sur moimême. (Reflexive diaries_Impro).

[On stage, I felt, in essence: my hands, my legs, the animal movement, a bit of savagery, very intimate connections, only shared with one or two people. And when distance was created, because sometimes we didn't understand each other, I found that we made interesting ruptures. A bit fragile at times, I wasn't too sure what I was doing, but I was testing, I was forgetting the gaze of others in the urgency to find it on myself].

Deuxième séance de danse. Premier exercice : prendre conscience de mes sens et contrôler mes mouvements. C'est incroyable comment il est difficile de se concentrer, mais que en même temps, on découvre une sensation nouvelle quand on le fait. C'est fou comment je ne suis presque jamais en contrôle de mes actions : tout est un automatisme si trivial. C'est aussi intéressant comment je gagne beaucoup de confiance quand je prends conscience du moment et de mes mouvements. (Reflexive diaries_Impro).

[Second dance session. First exercise: become aware of my senses and control my movements. It's incredible how difficult it is to concentrate, but at the same time you discover a new feeling when you do it. It's crazy how I'm almost never in control of my actions: everything is such a trivial automatism. It's also interesting how I gain a lot of confidence when I become conscious of the moment and my movements].

This second alternative of what we call "the body as a sensitive bridge" shows an awareness of "oneself" through bodily sensations. In other words, the body level of experience is also the way to an intimacy rarely noticed. In both courses, this perception of emotions linked to the body is enabled by the pedagogical setting. The activities proposed put on stage a dimension of the action 
that is frequently silenced in traditional educational systems. As a result, when this dimension is perceived in these contexts, it provokes surprise. Additionally, the diaries are a second instance of awareness and establish them in a written way or through some other material resource.

\section{The Body as a Condition for Biographical Continuity}

When students refer to their past experiences, especially those from childhood, they do so primarily by referring to bodily experiences. Attention to the bodily and affective experience brings out connections and resonances with past experiences from their biographies, especially with children's play. These early bodily sensations, gradually ignored in adult life, reappear, and students express diverse feelings in the diaries, like joy or shame. The radical child/adult discontinuity of Western cultures may lead to a radical critique of everything in the adult body that could be seen as childish. Under this condition, a wide range of experiences with the body are inhibited. Thus, in various passages of the diaries, we could see that the "childish" use of the body-mainly through play-is experienced as something uncomfortable or alibied. In these courses, however, the playful, exploratory and concrete dimensions are restored. Conversely, some students express pure joy to reconnect with their child experience.

\section{Box 10. The body as a Condition for Biographical Continuity}

\begin{abstract}
l'école: je peux courir dans tous les sens, rire et parler fort. Je peux m'exprimer comme bon me semble. Aujourd'hui on me donne cette opportunité. Quel bonheur celui de redevenir un peu enfant. (Reflexive diaries_Impro).

[This day reminds me a little bit of the little girl I was at the time of the breaks at school: I can run around, laugh and talk loudly. I can express myself any way I want. Today they give me this opportunity. What a joy it is to be a little child again].

Je me suis senti un peu enfante, libre de pouvoir m'exprimer de façon libre sans conditionnement, libre de pouvoir communiquer, libre de jouer avec les autres et aussi avec moi-même. Est difficile concrétiser et traduire en mots ce que j'ai prouvé mais quand le soir je suis rentré à la maison et j'ai appelé mes parents j'ai dit : « Écoutez, j’ai fait une expérience inoubliable que tout le monde devrait pouvoir faire ! Le binôme esprit / corps qui doit travailler avec la créativité donne lieu à des résultats étonnants. Dommage que je n'aie pas eu le courage avant de faire une telle activité. "
\end{abstract}

(Reflexive diaries_Impro).

[I felt a bit childish, free to express myself freely without conditioning, free to communicate, free to play with others and also with myself. It is difficult to materialize and put into words what I experienced, but when I came home in the evening and called my parents I said: "Listen, I had an unforgettable experience that everyone should be able to have! The mind/body pair that has to work with creativity produces amazing results. It's a shame I didn't have the courage to do something like this before"].

Au début du cours, Simon a demandé à l'assemblée si on avait des remarques ou quelque chose à propos des sessions qu'on avait eues jusqu'à présent. J'ai d'abord hésité à manifester à quel point je trouvais ce cirque ridiculement enfantin et peu adapté au niveau universitaire... Et puis quand j'ai entendu certains dire à quel point ils avaient trouvé ça riche, passionnant, intéressant, et plein de potentiel, je me suis dit que j'allais peut-être m'abstenir. (Reflexive diaries_Impro).

[At the beginning of the course, Simon asked the group if they had any comments or anything about the sessions they had had so far. At first, I was hesitant to express how ridiculously childish and unsuitable this circus was for me at the university level... Then when I heard some people saying how rich, exciting, interesting, and full of potential they found it, I thought maybe I would pass]. 
These fragments show the continuity established at the biographical level. We had previously pointed out how body-centred activities are a source for historicization. Here, we emphasize biographical continuity and the emergence, once again, of aspects of experience that are strongly inhibited by traditional education, such as playful exploration and other activities that are not in accordance with rational planning.

This biographical continuity is in clear contradiction with the split imposed by the education systems. We have already referred to the discontinuity between adult and child that characterizes Western societies. In these cases, counter-transferential emotional reactions are a sign of this conflict. Every time the continuity with childhood is re-established, the condemning reactions that were adopted as part of the ethos of the university student emerge.

\section{Final Discussion}

One question that guided our study is which are the meanings about the body that can be found in the diaries of students who face a course that invites them to place themselves on the edge of what is considered "normal" at the university? In other words, how do students, in a course that explicitly aims to subvert traditional material and symbolic organization, describe the bodily experience? What meanings emerge under these conditions and what are the common aspects of these definitions? Undoubtedly, meanings about the body are deeply related to the everyday practices of the subjects, and the symbolic and material spaces in which they take place. The paradigm of the split, around which traditional university education is organized, leads to experiences and representations that radically separate the body and the mind. This is why we believe that our results can contribute, not only to the specific discussion about the role of the performing arts in education but also to the way in which pedagogical interventions have impacts on the body-mind dichotomy.

Both courses redefine the instituted role of the body in higher education, through symbolic and material interventions. The body, as a spatial semiotic resource, implies at least two levels: (a) that of the situated sensory-motor experience-and therefore the relationship with other bodily experiences of the subjects-and (b) that of the sensory link with others-where the gaze plays a central role, in terms of exposure, revelation, concealment, suggestion, etc. These aspects are usually unnoticed in traditional settings, where the body is a static and divergent element, a kind of noise that must be avoided-and not merely ignored but is actively denied.

In accordance with the presented data, we would like to highlight some relevant aspects. On the one hand, the analysed courses do not seek to "add" physical activities to the traditional ones. The proposal is not simply to only expand the bodily experience into the educational setting but to reintroduce the processes of teaching and learning into the domain of the body. In other words, it is a matter of resetting or re-placing the central problem of education-how it is possible to promote the emergence of new knowledge in other subjects, in a directed way-in the domain of the bodily experience. In this sense, we can see a double pedagogical movement. The first is the one that gives back to the body its place in the educational scene. This first inversion is precisely that of making visible what is actively and continuously silenced. This challenge of conceiving the subject beyond the "prison of the mind" (Maresca, 2010) implies the revision of practices in all their classic dimensions. In this regard, there are three axes that should be problematized: 
(a) The relation between subjects and knowledge.

(b) The relationship between peers (subjects with other subjects in the same setting).

(c) The metacognition about bodily experiences in the process of teaching and learning.

But a second inversion also takes place here: the recognition of some educational problems in the field of the bodies. In this sense, the inversion is a dialectical solution, because what traditional education defined as the central problem of education is not completely rejected. On the contrary, this movement seeks to re-edit the problem of abstract reason and its possible educability, in the domain of bodily experience. Of course, the proposed turn should not be confused with a proposal to educate the body, but to educate from, and with, the body (Gallo, 2017).

The consequence of these inversions would be a redefinition of the notion of body, since the traditional somatic criterion used for its distinction is seriously disputed. If the body ceases to be conceptualized as the noise or interference that we must discipline and methodically separate from the process of knowledge production, if it is no longer a simple support or container of the mind, but rather participates in a central way in what we understand by knowledge, then its traditional limits are blurred. As we saw in the emerging meanings of the diaries, the body is much more than the sensory-perceptual dimension of the experience. It is a key dimension for historicization and for mediation between different institutional spheres. Or in other words, it has a bridging function that transcends the somatic experience. This last aspect of our study is what we think deserves the most attention and would require extensive analysis. Taken to its limit, this thesis does not require an a priori definition of the body-the stopping point of many theories about the embodied mind. The definition becomes operational and only emerges in the specificity of a particular context, with particular subjects creating something that cannot be predefined or standardized.

Another consequence we can draw from this study is that the pedagogical framework, through the proposed activities, defines and shapes the bodily experience in a deep manner. The known effects of dichotomic pedagogical models seem to be at least partially overcome in pedagogical proposals such as the ones we are analysing. From our data, we tried to trace the way in which the body emerges for the students, how they thematize it and the cognitive and emotional effects that this entails. The fact that we base our claims on an analysis of the students' diaries implies a focus, not on the lived experience but also on its representation. In other words, the focus of our analysis was the "consciousness" of the body and of the effects of this. In this process of reconstruction of the experience in representational terms, we can find the keys to a way of teaching that, through the body, allows to overcome the dichotomies established in traditional education. Restoring the body is not only, then, a fundamental pedagogical strategy for the integration of content in a social and biographical history but also for the restoration of fundamental resources for the creation and construction of new knowledge, resources that are often forgotten or actively rejected.

Funding Open Access funding provided by Université de Neuchâtel.

Open Access This article is licensed under a Creative Commons Attribution 4.0 International License, which permits use, sharing, adaptation, distribution and reproduction in any medium or format, as long as you give appropriate credit to the original author(s) and the source, provide a link to the Creative Commons licence, and indicate if changes were made. The images or other third party material in this article are included in the article's Creative Commons licence, unless indicated otherwise in a credit line to the material. If material is not included in the article's Creative Commons licence and your intended use is not 
permitted by statutory regulation or exceeds the permitted use, you will need to obtain permission directly from the copyright holder. To view a copy of this licence, visit http://creativecommons.org/licenses/by/4.0/.

\section{References}

Abbagnano, N., \& Visalberghi, A. (2015). Historia de la pedagogía. Fondo de Cultura Económica.

Abbey, E., \& Valsiner, J. (2004). Emergence of meanings through ambivalence. Forum Qualitative Sozialforschung / Forum: Qualitative Social Research, 6(1), Art. 23.

Alanen, L. (2009). Descartes's concept of mind. Harvard University Press.

Álvarez Hidalgo, J. (2017). El enactivismo como superación teórica de la visión dualista y abstracta del cognitivismo (Doctoral dissertation, Universidad Alberto Hurtado, Chile).

Amin, T. G., \& Valsiner, J. (2004). Coordinating operative and figurative knowledge. Piaget, Vigotsky, and Beyond. In J. Carpendale, \& U. Müller (Eds.), Social interaction and the development of knowledge (pp. 87-109). Lawrence Associates Publishers.

Assalone, E., \& Misseri, L. (2010). El giro subjetivista de la Filosofía Moderna. Ediciones Cátedra de Filosofía Moderna.

Barnacle, R. (2009). Gut instinct: the body and learning. Educational Philosophy and Theory, 41(1), 22-33.

Barsalou, L. W., Niedenthal, P. M., Barbey, A. K., \& Ruppert, J. A. (2003). Social embodiment. Psychology of learning and motivation, 43, 43-92.

Becerra, G., \& Castorina, J. A. (2016). Acerca de la noción de "marco epistémico" del constructivismo. Una comparación con la noción de "paradigma" de Kuhn. CTS: Revista iberoamericana de ciencia, tecnología y sociedad, 11(31), 9-28.

Benarós, S., Lipina, S. J., Segretin, M. S., Hermida, M. J., \& Colombo, J. A. (2010). Neurociencia y educación: hacia la construcción de puentes interactivos. Revista de neurología, 50(3), 179-186.

Bergen, B. K. (2012). Louder than words: the new science of how the mind makes meaning. Basic Books.

Bickle, J. (2006). Reducing mind to molecular pathways: explicating the reductionism implicit in current cellular and molecular neuroscience. Synthese, 151(3), 411-434.

Bidell, T. (1988). Vygotsky, Piaget and the dialectic of development. Human Development, 31(6), $329-348$.

Bresler, L. (Ed.). (2013). Knowing bodies, moving minds: towards embodied teaching and learning (Vol. 3). Springer Science \& Business Media.

Bunge, M., \& Ardila, R. (1987). Why philosophy of psychology? Philosophy of Psychology (pp. 3-24). Springer.

Bunglowala, A., \& Bunglowala, A. (2015). Non-verbal communication: an integral part of teaching learning process. International Journal of Research in Advent Technology Special, 1, 371-375.

Burdman, F. (2015). El post-cognitivismo en cuestión: extensión, corporización y enactivismo. Principia, 19, 475-495. https://doi.org/10.5007/1808-1711.2015v19n3p475

Castorina, J. A. (2002). El impacto de la filosofía de la escisión en la psicología del desarrollo cognoscitivo. Psykhe, 11(1), 15-27.

Castorina, J. A. (2016). La relación problemática entre Neurociencias y educación Condiciones y análisis crítico. Propuesta educativa, 46, 26-41.

Castorina, J. A. (2020). The importance of worldviews for developmental psychology. Human Arenas [online]. https://doi.org/10.1007/s42087-020-00115-9

Castorina, J. A., \& Baquero, R. (2005). Dialéctica y psicología del desarrollo: el pensamiento de Piaget y Vigotsky. Amorrortu.

Compayré, G. (2015). The history of pedagogy. Routledge.

Craig, C., You, J., Zou, Y., Verma, R., Stokes, D., Evans, P., \& Curtis, G. (2018). The embodied nature of narrative knowledge: a cross-study analysis of embodied knowledge in teaching, learning, and life. Teaching and Teacher Education, 71, 329-340.

Dall'Alba, G., \& Barnacle, R. . (2005). Embodied knowing in online environments. Educational Philosophy and Theory, 37(5), 719-744.

Dall'Alba, G., \& Barnacle, R. (2007). An ontological turn for higher education. Studies in Higher Education, 32(6), 679-691. https://doi.org/10.1080/03075070701685130

Damasio, A. (1994). Descartes' error: emotion, reason, and the human brain. Avon Books.

Davis, H. E. (1996). Docile bodies and disembodied minds. Educational Theory, 46(4), 525-543.

Di Paolo, E. (2013). El enactivismo y la naturalización de la mente. In D. Chico, \& M. Bedia, Nueva ciencia cognitiva: Hacia una teoría integral de la mente. Madrid: Plaza y Valdes Editores.

Dixon, M., \& Senior, K. (2011). Appearing pedagogy: from embodied learning and teaching to embodied pedagogy. Pedagogy, Culture \& Society, 19(3), 473-484. 
Druyan, S. (1997). Effect of the kinesthetic conflict on promoting scientific reasoning. Journal of Research in Science Teaching: The Official Journal of the National Association for Research in Science Teaching, 34(10), 1083-1099.

Duveen, G. (1997). Psychological development as a social process. In L. Smith, J. Drokwell, \& P. Tomlinson (Eds.), Piaget, Vygotski, and beyond (pp. 67-90). Routledge.

Elo, S., \& Kyngäs, H. (2008). The qualitative content analysis process. Journal of Advanced Nursing, 62, 107-115. https://doi.org/10.1111/j.1365-2648.2007.04569.x

Engeström, Y. (2018). Expertise in transition: expansive learning in medical work. Cambridge University Press.

Evans, J., Davies, B., \& Rich, E. (2009). The body made flesh: embodied learning and the corporeal device. British journal of sociology of education, 30(4), 391-406.

Feigl, H. (1950). The mind-body problem in the development of logical empiricism. Revue internationale de Philosophie, 64-83.

Ferreiro, E. (1997). Alfabetización: teoría y práctica. Siglo XXI Editores.

Ferreiro, E. (2001). On the links between equilibration, causality and 'prise de conscience' in Piaget's theory. Human Development, 44(4), 214-219.

Foucault, M. (1957). La psychologie de 1850 à 1950. Dans D. Huisman \& A. Weber, Histoire de la philosophie européenne, t. II. Paris: Librairie Fischbacher.

Foucault, M. (1975). Surveiller et punir, naissance de la prison. Gallimard.

Foucault, M. (1976). Histoire de la sexualité. Vol. 1. La Volonté de savoir. Paris: Gallimard.

Fox, D., Prilleltensky, I., \& Austin, S. (Eds). (2009). Critical psychology. SAGE.

Freire, P. (1970). Pedagogy of the oppressed. Herder and Herder.

Freire, P. (1996). Política y educación. Siglo XXI.

Freire, P. (2006[1970]). The banking model of education. In E. F. Provenzo (ed.). Critical issues in education: an anthology of readings. (pp. 105-117). Thousand Oaks, CA: Sage Publications.

Ferreiro, E., Pontecorvo, C., Ribeiro Moreira, N., \& García Hidalgo, I. (1996). Caperucita Roja aprende a escribir. Gedisa.

Gallagher, S., \& Lindgren, R. (2015). Enactive metaphors: learning through full-body engagement. Educational Psychological Review, 27, 391-404. https://doi.org/10.1007/s10648-015-9327-1

Gallo, L. E. (2017). Una didáctica performativa para educar (desde) el cuerpo. Revista Brasileira de Ciências do Esporte, 39(2), 199-205. https://doi.org/10.1016/j.rbce.2016.09.002

García, R. (2000). El conocimiento en construcción: De las formulaciones de Jean Piaget a la teoría de sistemas complejos. Gedisa.

García, R. (2006). Sistemas complejos. Gedisa.

Gardner, H. (1987). The mind's new science: a history of the cognitive revolution. Basic books.

Gaukroger, S. (1995). Descartes: an intellectual biography. Clarendon Press.

Gilbert, R. (1949). The Concept of Mind. Hutchinson University Library.

Gillespie, M. A. (2008). The theological origins of modernity. University of Chicago Press.

Giroux, H. A. (1992). Border crossing. Cultural Workers and the Politics of Education. New York \& London: Routledge.

Glenberg, A. (2010). Embodiment as a unifying perspective for psychology Wiley Interdisciplinary Reviews. Cognitive Science, 1(4), 586-596.

Glenberg, A. M. (2017). How reading comprehension is embodied and why that matters. International Electronic Journal of Elementary Education, 4(1), 5-18.

Gobert, R. D. (2013). The mind-body stage: passion and interaction in the Cartesian Theater. Stanford University Press.

Gómez, R. (2014). La dimensión valorativa de las ciencias. Editorial de la Universidad Nacional de Quilmes.

Greimas, A. J. (1973). Du sens : essais sémiotiques. Le Seuil.

Haenlein, M., \& Kaplan, A. (2019). A brief history of artificial intelligence: on the past, present, and future of artificial intelligence. California management review, 61(4), 5-14.

Hill, J. (2018). The Cartesian element in Locke's anti-Cartesian conception of body. In P. Hamou \& M. Pécharman, Locke and Cartesian Philosophy (e-book). Oxford: OUP.

Hodkinson, P., Biesta, G., \& James, D. (2008). Understanding learning culturally: overcoming the dualism between social and individual views of learning. Vocations and learning, 1(1), 27-47.

Holton, D. L. (2010). Constructivism+embodied cognition= enactivism: theoretical and practical implications for conceptual change. In AERA 2010 Conference.

Ignatow, G. (2007). Theories of embodied knowledge: new directions for cultural and cognitive sociology? Journal for the Theory of Social Behaviour, 37, 115-135. https://doi.org/10.1111/j.1468-5914.2007. 00328.x 
Kazan, T. S. (2005). Dancing bodies in the classroom: moving toward an embodied pedagogy. Pedagogy, 5(3), 379-408.

Krippendorff, K. (1980). Content analysis. An introduction to its methodology. Sage.

Lakoff, G., \& Johnson, M. (1999a). Philosophy in the flesh: the embodied mind and its challenge to western thought. Basic Books.

Lakoff, G., \& Johnson, M. (1999b). Philosophy in the flesh. The embodied mind and its challenge to Western thought. Basic Books.

Leary, D. E. (Ed.). (1994). Metaphors in the history of psychology. Cambridge University Press.

Lokhorst, G. J. C., \& Kaitaro, T. T. (2001). The originality of Descartes theory about the pineal gland. Journal of the History of the Neurosciences, 10(1), 6-18.

López-Muñoz, F., Alamo, C., \& García-García, P. (2010). La neurofisiología cartesiana: entre los spiritus animalis y el conarium. Archivos de Neurociencias, 15(3), 179-193.

Luzuriaga, L. (1997). Historia de la educación y de la pedagogía. Losada.

Maresca, S. (2010). La cárcel de la mente. Para una Historia de la subjetividad moderna. En E. Assalone \& L. Misseri (comp.), El giro subjetivista de la Filosofía Moderna (pp. 298-335). Mar del Plata: Ediciones Cátedra de Filosofía Moderna.

Marshall, J. (2017). Contemporary debates in education studies. Routledge.

Matthews, J. C. (1994). Mindful body, embodied mind: somatic knowledge and education. Doctoral dissertation. Standford: Stanford University.

Mayring, P. (2004). Qualitative content analysis. a companion to qualitative research, 1(2004), 159-176.

Mayring, P. (2015) Qualitative content analysis: theoretical Background and procedures. In: A. Bikner-Ahsbahs, C. Knipping \& N. Presmeg (Eds.), Approaches to Qualitative Research in Mathematics Education (pp. 365-380). Springer.

Mayring, P. (2019). Qualitative content analysis: demarcation, varieties, developments. Forum Qualitative Sozialforschung/Forum: Qualitative Social Research, 20(3).

McNeill, D. (1992). Hand and mind: what gestures reveal about thought. University of Chicago press.

Molander, B. (2009). What is 'hidden' and what is not? Eigen-Sinn und Widerstand (pp. 54-69). VS Verlag für Sozialwissenschaften.

Molesworth, M., Scullion, R., \& y Nixon, L. (2011). The marketisation of higher education and the student as consumer. Routledge.

Moon, J. A. (2006). Learning journals. A handbook for reflective practice and professional development. Routledge.

Nedbalová, E., Greenacre, L., \& Schulz, J. (2014). UK higher education viewed through the marketization and marketing lenses. Journal of Marketing for Higher Education, 24, 178-195. https://doi.org/10. 1080/08841241.2014.973472

Nguyen, D. J., \& Larson, J. B. (2015). Don't forget about the body: exploring the curricular possibilities of embodied pedagogy. Innovative Higher Education, 40(4), 331-344.

Núñez, R. E., Edwards, L. D., \& Filipe Matos, J. (1999). Embodied cognition as grounding for situatedness and context in mathematics education. Educational Studies in Mathematics, 39, 45-65.

Overton, W. F. (1991). Metaphor, recursive systems, and paradox in science and developmental theory. Advances in child development and behavior, 23, 59-71.

Overton, W. F. (1994). Contexts of meaning: the computational and the embodied mind. In W. Overton \& D. Palermo (Eds.), The nature and ontogenesis of meaning (pp. 1-18). Lawrence Erlbaum.

Overton, W. F. (1997). Beyond dichotomy: an embodied active agent for cultural psychology. Culture and Psychology, 3(3), 315-334.

Overton, W. F. (1998). Developmental psychology: philosophy, concepts, and methodology. In W. Damon \& R. M. Lerner (Eds.), Handbook of child psychology (pp. 107-188). Wiley.

Overton, W. F. (2006). Developmental psychology: philosophy, concepts, methodology. In W. Damon, R. M. Lerner (Eds.), Handbook of child psychology. Vol. 1: Theoretical models of human development (6th ed., pp. 18-88). Hoboken: Wiley.

Overton, W. F. (2007). A coherent metatheory for dynamic systems: relational organicism-contextualism. Human Development, 59, 154-159.

Overton, W. F., \& Müller, U. (2012). Metatheories, theories, and concepts in the study of development. In I. B. Weiner, R. M. Lerner, \& M. A. Easterbrooks (Eds.), Handbook of Psychology (pp. 19-58). John Wiley \& Sons.

Overton, W., Mueller, U., \& Newman, J. (Eds.). (2008). Developmental perspectives on embodiment and consciousness. Lawrence Erlbaum Associates.

Oyama, S. (1999). Locating development: locating developmental systems. In E. Scholnick, K. Nelson, S. Gelman \& P. Miller (Eds), Conceptual development. Piaget's legacy (pp. 185-208). Mahwah, NJ: Lawrence Erlbaum Associates. 
Paechter, C. (2004). "Mens sana in corpore sano": Cartesian dualism and the marginalisation of sex education. Discourse: studies in the cultural politics of education, 25(3), 309-320.

Perkin, H. (2007). History of universities. International handbook of higher education (pp. 159-205). Springer.

Piaget, J. (1974). La prise de conscience. PUF.

Piaget, J., \& García, R. (1982). Psicogénesis e historia de la ciencia. Siglo XXI.

Planella, J. (2006). Cuerpo, cultura y educación. Desclée de Brouwer.

Probyn, E. (2004). Teaching bodies: affects in the classroom. Body \& Society, 10(4), 21-43.

Puiggrós, A. (2017). Adiós, Sarmiento. Educación pública, Iglesia y mercado. Buenos Aires: Ediciones Colihue.

Quine, W. O. (1976). Two dogmas of empiricism. In S. G. Harding (Ed.), Can Theories be Refuted? (pp. 41-64). Holland.

Rivière, A. (1988). Objetos con mentes. Alianza editorial.

Rodó, A., \& Saball, P. (1994). El cuerpo ausente. Debate feminista, 10, 81-94.

Rodríguez Gómez, G., Gil Flores, J., \& García Jiménez, E. (1996). Reducción de datos. Metodología de la Investigación cualitativa (pp. 204-212). Granada.

Rom, R. B. (1998). "Safe spaces": reflections on an educational metaphor. Journal of Curriculum studies, 30(4), 397-408.

Samaja, J. (2006). El puesto de la lengua en la comunidad, el estado y la sociedad civil. Diagnosis, 3.

Samuel, G., \& Geoffrey, S. (1990). Mind, body and culture: anthropology and the biological interface. Cambridge University Press.

Scharagrodsky, P. (2007). El cuerpo en la escuela. Buenos Aires: Ministerio de Educación, Ciencia y Tecnología. [http://sedici.unlp.edu.ar/handle/10915/93480].

Searle, J. R. (1992). The rediscovery of the mind. MIT press.

Searle, J. R. (2004). Mind: a brief introduction. Oxford University Press.

Seitz, J. A. (2000). The bodily basis of thought. New ideas in Psychology, 18(1), 23-40.

Shapiro, L. A. (Ed.). (2014). The Routledge handbook of embodied cognition. Routledge.

Shapiro, L. A. (2004). The mind incarnate. MIT Press.

Sharkey, N., \& Ziemke, T. (2001). Mechanistic vs. phenomenal embodiment - Can robot embodiment lead to strong AI? Cogn. Systems Res., 2(4), 251-262.

Shoval, E. (2011). Using mindful movement in cooperative learning while learning about angles. Instructional Science, 39(4), 453-466.

Sidhu, R. K., \& Dall'Alba, G. (2012). International education and (dis) embodied cosmopolitanisms. Educational philosophy and theory, 44(4), 413-431.

Stolz, S. A. (2015). Embodied learning. Educational philosophy and theory, 47(5), 474-487.

Streeck, J., Goodwin, C., \& LeBaron, C. (Eds.). (2011). Embodied interaction: language and body in the material world. Cambridge University Press.

Tau, R., \& Parrat-Dayan, S. (2018). Educación y mercantilización. La construcción del sujeto normalizado. Desde la patagonia. Difundiendo saberes, 15(26), 38-42.

Teo, T. (2011). Radical philosophical critiques and critical thinking in psychology. Journal of Theoretical and Philosophical Psychology, 11(3), 193-199.

Thelen, E. (2000). Grounded in the world: developmental origins of the embodied mind. Infancy, 1(1), 3-28.

Thelen, E., \& Smith, L. B. (1990). Dynamics systems theories. In W. Damon \& M. L. Lerner (Eds.), Handbook of child psychology (pp. 563-634). Wiley.

Turner, B. S., \& Turner, B. S. (1992). Regulating bodies: Essays in medical sociology. Psychology Press.

Valsiner, J. (1998). The development of the concept of development: historical and epistemological perspectives. In W. Damon \& M. L. Lerner (Eds.), Handbook of child psychology (pp. 189-232). Wiley.

Valsiner, J. (2007). Culture in minds and societies: Foundations of cultural psychology. SAGE.

Valsiner, J. (2013). Cultural psychology. In K. D. Keith (Ed.), The encyclopedia of cross-cultural psychology (pp. 319-327). John Wiley \& Sons.

Valsiner, J. (2017). A guided science: history of psychology in the mirror of its making. Routledge.

Valsiner, J. (2018). The concept of attractor. In G. Marsico \& J. Valsiner (Eds.), Beyond the Mind: Cultural Dynamics of the Psyche (pp. 97-113). IAP.

Valsiner, J. (2019). Cultural psychology as a theoretical project. Estudios de Psicología, 40(1), 10-47.

Van der Veer, R. (1987). El dualismo en psicología: un análisis vigotskiano. Actualidad de Lev S. Vigotski, $3,87-101$.

Van Geert, P. (2003). Dynamic systems approaches and modeling of developmental processes. In J. Valsiner \& K. J. Conolly (Eds.), Handbook of developmental Psychology (pp. 640-672). Sage.

Varela, C. (1995). Cartesianism revisited: the ghost in the moving machine or the lived body. Human action signs in cultural context: the visible and the invisible in movement and dance, 216-293. 
Varela, F. (2010). El fenómeno de la vida. Comunicaciones Noreste Ltda.

Varela, F. J., Thompson, E., \& Rosch, E. (1991). The embodied mind: cognitive science and human experience. MIT Press.

Vasilachis de Gialdino, I. (2006). Estrategias de investigación cualitativa. Gedisa.

Villoro, L. (2013). El pensamiento moderno: filosofía del Renacimiento. Fondo de Cultura Económica.

Watzlawick, P., Bavelas, J. B., \& Jackson, D. D. (2011). Teoría de la comunicación humana: interacciones, patologías y paradojas. Herder Editorial.

Welton, D. (1999). The body: classic and contemporary readings. Wiley.

Winch, C. (2002). The philosophy of human learning. Routledge.

Witherington, D. C. (2007). The dynamic systems approach as metatheory for developmental psychology. Human Development, 50, 127-153.

Wright, J. P., \& Potter, P. (2000). Psyche and soma: physicians and metaphysicians on the mind-body problem from antiquity to enlightenment. Oxford Clarendon Press.

Ziemke, T., et al. (1999). Rethinking grounding. In A. Riegler (Ed.), Understanding representation in the cognitive science (pp. 177-190). Plenum Press.

Ziemke, T. (2003). What's that thing called embodiment? Proceedings of the annual meeting of the cognitive science society, 25, 1305-1310.

Zlatev, J. (1997). Situated embodiment. Studies in the emergence of spatial meaning. Gotab.

Zlatev, J. (2001). The epigenesis of meaning in human beings, and possibly in robots. Minds and Machines, 11, 155-195.

Publisher's Note Springer Nature remains neutral with regard to jurisdictional claims in published maps and institutional affiliations. 